\title{
Extraction and degradation of chlorophyll $a$ and $b$ from Alternanthera sessilis
}

\author{
M.A.M. Jinasena ${ }^{1}$, A.D.U.S. Amarasinghe ${ }^{2}$, B.M.W.P.K. Amarasinghe ${ }^{2}$ and M.A.B. Prashantha ${ }^{3}$ \\ ${ }^{1}$ Department of Chemical and Process Engineering, Faculty of Engineering, University of Peradeniya, Peradeniya. \\ ${ }^{2}$ Department of Chemical and Process Engineering, Faculty of Engineering, University of Moratuwa, Katubedda, Moratuwa. \\ ${ }^{3}$ Department of Chemistry, Faculty of Applied Sciences, University of Sri Jayewardenepura, Gangodawila, Nugegoda.
}

Revised: 20 March 2015; Accepted: 26 August 2015

\begin{abstract}
The use of Alternanthera sessilis, which is commonly known as Mukunuwenna in Sri Lanka as a source of chlorophyll was examined. The extraction of chlorophyll was carried out using buffered $80 \%(\mathrm{v} / \mathrm{v})$ aqueous acetone. The optimum operating conditions such as solvent to $A$. sessilis ratio, extraction temperature and extraction time were found to be $5 \mathrm{~mL} / \mathrm{g}, 50{ }^{\circ} \mathrm{C}$ and 45 minutes, respectively. The yield of chlorophyll $a$ and chlorophyll $b$ under these optimum operating conditions were 659 and $261 \mu \mathrm{g} / \mathrm{g}$ of $A$. sessilis, respectively. Mechanical grinding of $A$. sessilis gave a higher yield as compared to blanching and drying. Refrigeration at $15^{\circ} \mathrm{C}$ was found to be ideal for storing of fresh $A$. sessilis up to 3 days without a considerable loss of chlorophyll content. Chlorophyll extraction could be modelled successfully using basic mass transfer equations up to $30{ }^{\circ} \mathrm{C}$. It failed above this temperature due to the degradation effect. Kinetic study on the degradation of chlorophyll extracted from A. sessilis confirmed first order reaction model and the effect of temperature on the rate constant was also adequately modelled by the Arrhenius equation.
\end{abstract}

Keywords: Alternanthera sessilis, chlorophyll degradation, chlorophyll extraction, kinetics, mass transfer, operating condition.

\section{INTRODUCTION}

Chlorophyll is the green pigment found in plants, and is formed in the chloroplasts of the plant cells influenced by sunlight. This pigment is necessary for the process of photosynthesis. Chlorophyll exists mainly as chlorophyll $a$ and chlorophyll $b$.

Chlorophyll and chlorophyll derivatives, which are known as chlorophyllin, are widely used in industry as a stable, non-toxic, physiologically harmless colourant for dairy products, edible oils, soups, chewing gums, sugar confections, drinks, cosmetics, toiletries and medicines (Madrid \& Madrid, 1990; Francis, 2000; Marquez \& Borrmann, 2009). Various therapeutic properties of chlorophyll such as anti-inflammatory activity, acceleration of wound healing, immune modulator properties and body deodorisation in geriatric and ileostomy patients have been reported (Chernomorsky \& Segelman, 1988). Furthermore, the anti-mutagenic and anti-carcinogenic activities of chlorophyll and its derivatives have been proposed (Matney, 1980; Dashwood et al., 1991; Sarkar et al., 1994; Ferruzi et al., 2002; Ferruzzi \& Blakeslee, 2007). Due to the anti-oxidant, anti-atherogenic, anti-inflammatory and detoxification properties of chlorophyll and its derivatives, it is used in medicines and food supplements (Chernomorsky et al., 1999; Kamat et al., 2000; Fernandes et al., 2007; Ferruzzi \& Blakeslee, 2007). Chlorophyll can also be used to produce fuel additives to enhance the combustion characteristics of carbonaceous fuels (Jordan, 1998). The potential of the photo-conversion efficiency of a chlorophyll derivative in dye-sensitised solar cells have also been studied (Wang et al., 2005).

The production of chlorophyll from algae and higher plants is a key topic of scientific and commercial interest. Chlorophyll is widely extracted for industrial applications from stinging nettle, spinach, algae (Macias-Sanchez et al., 2007), silkworm excreta, alfalfa, pine needles, other pasture grasses and plant harvest by-products (Marquez \& Borrmann, 2009). 
Alternanthera sessilis (L.) R. Br. ex D.C., which is commonly known as sessile joy weed or dwarf copperleaf around the world, while it is known as Mukunuwenna (Sinhala) or Ponnannkannjkkirai (Tamil) in Sri Lanka, was selected because of the low cost, ready availability and medicinal and nutritional value. A. sessilis is a perennial plant belonging to the class Magnoliopsida of the family Amaranthaceae. It is widespread throughout the tropics and subtropics. This plant is commonly used as a leafy vegetable and a medicine in Sri Lanka. A. sessilis is used in Ayurveda for the treatment of biliousness, chronic congestion of liver, acute and chronic pyelitis, cystitis, gonorrhea, and snake bite in Sri Lanka (Gayathri et al., 2006). Further, its antimicrobial properties, wound healing abilities (Jalalpure et al., 2008) and the ability to increase the production of milk in nursing mothers (Jayaweera, 1981) have also been reported. The objective of the present study was to evaluate A. sessilis as a potential source of extractable chlorophyll and to examine the ideal extraction, pre-processing and storage conditions. The applicability of general mass transfer equations in modelling the chlorophyll extraction was also examined.

There are a few different forms of chlorophyll that occur naturally. Since the most widely distributed forms in the terrestrial plants are chlorophyll $a$ and $b$, the study was focused on those two forms. Various solvents such as aqueous acetone, methanol, ethanol and dimethylsulfoxide (DMSO) are used for the extraction of chlorophyll (Shoaf \& Lium, 1976; Sartory \& Grobbelaar, 1984; Simon \& Helliwell, 1998; Porra et al., 1999). Although methanol, ethanol and DMSO proved to be superior to acetone (Sartory \& Grobbelaar, 1984; Barnes et al., 1992), $80 \%$ acetone was selected as the solvent in the present study since it is the most suitable solvent for the selected quantification method (Lichtenthaler, 1987; Wellburn, 1994), produces a more stable product, is cheaper and less toxic (Thompson et al., 1999).

Food that have added commercial chlorophyll are processed thermally for microbiological safety; nevertheless, the addition of heat to food causes losses in texture, flavour, colour, and nutrients. The stability of chlorophyll is mainly affected by temperature (Ryan-Stoneham \& Tong, 2000). The kinetics of chlorophyll degradation have been studied on a variety of vegetables, including spinach (Canjura et al., 1991), snapbeans, okra and turnip greens (Jones et al., 1963), asparagus, green beans and green peas (Hayakawa \& Timbers, 1977), broccoli (Sweeney \& Martin, 1958) as well as on chlorophyll derivatives (Koca et al., 2007). Generally, chlorophyll degradation has been shown to follow a first-order model (Hayakawa \& Timbers,
1977; Lichtenthaler, 1987; Canjura et al., 1991; Steet \& Tong, 1996; Ryan-Stoneham \& Tong, 2000; Koca et al., 2007; Erge et al., 2008; Rudra et al., 2008; Seema $\&$ Keshav, 2010). The effect of temperature on the rate constant was also adequately modelled by the Arrhenius equation (Lichtenthaler, 1987; Ryan-Stoneham \& Tong, 2000; Koca et al., 2007). The degradation kinetics of the chlorophylls extracted from $A$. sessilis was examined in the present work to ensure the prediction of quality loss during thermal processing and storage.

\section{METHODS AND MATERIALS}

\section{Materials}

Mature and healthy $A$. sessilis samples were collected from a farm in Kesbewa, Sri Lanka. All parts of the plant except the roots were taken to prepare the samples. Double distilled acetone (analytical grade) was used as the solvent. A buffer solution of $\mathrm{pH} 7.8$ was prepared with sodium dihydrogen phosphate and disodium hydrogen phosphate.

\section{Analytical technique}

A dual beam recording UV-visible spectrophotometer (Shimadzu: model 1800) with $1 \mathrm{~cm}$ square glass cuvettes was used to determine the chlorophyll concentration. A Panasonic MX-AC-300 mixer-grinder was used for mechanical grinding of $A$. sessilis and REMI R-4C laboratory centrifuge was used to centrifuge the extract.

Aqueous acetone with a concentration of $80 \%(\mathrm{v} / \mathrm{v})$ was used as the solvent and $2.5 \mathrm{mM}$ phosphate buffer of pH 7.8 was added to the solvent. Fresh A. sessilis ( $5 \mathrm{~g}$ ) were cut into pieces and ground using the mixer-grinder. The ground $A$. sessilis was added to the solvent and placed in a water bath. The extraction was carried out in a dark environment with frequent agitation. After the extraction, samples were centrifuged for $10 \mathrm{~min}$ at 2,000 rpm and the supernatant was separated for analysis of chlorophyll.

Chlorophyll concentrations were determined using the spectrophotometer according to the procedure used by Wellburn (1994) and Lichtenthaler (1987). Absorption spectrum was recorded in the UV-visible spectrophotometer. The solutions were diluted using the solvent ( $80 \%$ acetone) to obtain the absorbance values in the range of 0.1 to 0.7 . The concentrations of chlorophyll $a, b$ and $a$ plus $b$ were calculated using the following formulae (Lichtenthaler, 1987; Wellburn, 1994).

$C_{a}=12.25 A^{663.2}-2.79 A^{646.8}$ 
$C_{b}=21.5 A^{646.8}-5.1 A^{663.2}$

$C_{a+b}=7.15 A^{663.28}+18.71 A^{646.8}$

Where $\mathrm{A}^{646.8}$ and $\mathrm{A}^{663.2}$ are the absorbance at wave lengths 646.8 and $663.2 \mathrm{~nm}$, respectively. $\mathrm{C}_{a}$ and $\mathrm{C}_{b}$ are the concentrations of chlorophyll $a$ and $b$ in plant extract in micrograms per millilitre, respectively.

Concentrations of the extracts were calculated by multiplying the concentrations of diluted samples with the respective dilution factor. The weights of chlorophyll $a, b$ and $a$ plus $b$ were calculated by multiplying the concentrations of chlorophyll $a, b$ and $a$ plus $b$ with the volume of the sample. Experiments were triplicated and the average value was taken. The weights have been expressed on wet basis unless stated otherwise.

\section{Optimum solvent volume to $A$. sessilis ratio}

Chlorophyll was extracted by following the analytical techniques described previously. Solvent volume to A. sessilis weight ratio was changed from 3 to $10 \mathrm{~mL} / \mathrm{g}$. Temperature of the water bath was kept at $30{ }^{\circ} \mathrm{C}$ and the extraction time was selected as $300 \mathrm{~min}$ in order to provide sufficient time for the extraction of chlorophyll.

\section{Optimum temperature of extraction}

Solvent volume to $A$. sessilis ratio was taken as $5 \mathrm{~mL} / \mathrm{g}$ based on the results of the previous experiment. Five water baths were maintained at temperatures 20, 30, 40,50 and $60{ }^{\circ} \mathrm{C}$. The extraction time varied from
60 to 300 min with $60 \mathrm{~min}$ interval. Five samples were tested for each temperature and extraction time.

\section{Optimum time for extraction}

A solvent volume to $A$. sessilis ratio of $5 \mathrm{~mL} / \mathrm{g}$ and an extraction temperature of $50{ }^{\circ} \mathrm{C}$ was selected based on the results of the previous experiments. The extraction time varied from $15 \mathrm{~min}$ to $60 \mathrm{~min}$ with $15 \mathrm{~min}$ intervals, and then up to 300 min with 60 min intervals.

\section{Effective storage conditions for $A$. sessilis}

In order to determine the effective method of storage for harvested A. sessilis, six commonly used storage conditions were tested (Table 1).

\section{Effective method of pre processing of $A$. sessilis}

Five different commonly used pre-processing methods were used to disintegrate the structure of the plant cells as described in Table 2.

\section{Kinetics of chlorophyll degradation}

Four samples of fresh $A$. sessilis were prepared for extraction by the method Pre 1 (Table 2). Solvent to A. sessilis ratio of $5 \mathrm{~mL} / \mathrm{g}$, temperature of $50{ }^{\circ} \mathrm{C}$ and time of $45 \mathrm{~min}$ were selected as the extraction conditions based on the results of previous experiments. The extracted chlorophyll samples as solutions were used to examine the degradation kinetics at four different temperatures; 15, 30, 40 and $50^{\circ} \mathrm{C}$. This temperature range was selected based on the normal storage and transportation conditions and the possible processing temperatures. Each sample was tested for chlorophyll $a$ and $b$ for $0-6$ hours at 1 hour

Table 1: Tested storage conditions for the determination of effective storage conditions for harvested A. sessilis

\begin{tabular}{|c|c|}
\hline $\begin{array}{l}\text { Storage } \\
\text { condition }\end{array}$ & Description \\
\hline Env 1 & $\begin{array}{l}\text { Fresh } A \text {. sessilis was stored in a closed container in a freezer section of a refrigerator, where the average temperature was } \\
5 \pm 2{ }^{\circ} \mathrm{C} \text { and relative humidity }(\mathrm{RH}) \text { was } 50 \pm 2 \% \text {. }\end{array}$ \\
\hline Env 2 & $\begin{array}{l}\text { Fresh } A \text {. sessilis was stored in a closed container in a cooler section of a refrigerator, where the average temperature was } \\
15 \pm 2{ }^{\circ} \mathrm{C} \text { and RH was } 60 \pm 2 \%\end{array}$ \\
\hline Env 3 & Fresh $A$. sessilis was stored in open air, where the average temperature was $32 \pm 2{ }^{\circ} \mathrm{C}$ and $\mathrm{RH}$ was $76 \pm 2 \%$ \\
\hline Env 4 & Fresh $A$. sessilis was stored in a closed dark container, where the average temperature was $32 \pm 2{ }^{\circ} \mathrm{C}$ and $\mathrm{RH}$ was $76 \pm 2 \%$ \\
\hline Env 5 & $\begin{array}{l}\text { Fresh } A \text {. sessilis was dried in an oven for six hours (until weight becomes a constant) at a temperature of } 40 \pm 2{ }^{\circ} \mathrm{C} \text { and then } \\
\text { stored in a closed transparent container, where RH was } 76 \pm 2 \%\end{array}$ \\
\hline Env 6 & $\begin{array}{l}\text { Fresh } A \text {. sessilis was dried in an oven at a temperature of } 70 \pm 2{ }^{\circ} \mathrm{C} \text { until weight becomes a constant (about four hours) and } \\
\text { then stored in a closed transparent container, where } \mathrm{RH} \text { was } 76 \pm 2 \%\end{array}$ \\
\hline
\end{tabular}


Table 2: Tested pre processing methods for the determination of the effective pre processing method

\begin{tabular}{ll}
\hline Method & \multicolumn{1}{c}{ Description } \\
\hline Pre 1 & Fresh A. sessilis was cut (1 inch pieces) and then ground for 5 minutes using the mixer-grinder. \\
Pre 2 & $\begin{array}{l}\text { Fresh } A \text {. sessilis was blanched by soaking the samples in hot water at a temperature of } 95{ }^{\circ} \mathrm{C} \text { for one } \\
\text { minute and then immediately dipping it in cold water at a temperature of } 15^{\circ} \mathrm{C} \text { for two minutes (Chandrika } \\
\text { et al., 2006). Then the samples were cut into pieces of one inch length, approximately. }\end{array}$ \\
Pre 3 & $\begin{array}{l}\text { Fresh } \text { A. sessilis was blanched following the procedure in Pre } 2 \text { and then ground for } 5 \text { minutes using the } \\
\text { mixer-grinder. }\end{array}$ \\
Pre 4 & Fresh A. sessilis was ground using mortar and pestle. \\
Pre 5 & Fresh $A$. sessilis was dried in an oven for six hours at a temperature of $40{ }^{\circ} \mathrm{C}$ and then ground manually. \\
\hline
\end{tabular}

intervals. The average of duplicated experiments was used for the analysis.

\section{RESULTS AND DISCUSSION}

\section{Optimum extraction conditions}

\section{Optimum solvent volume to A. sessilis ratio}

Figure 1 indicates that the maximum chlorophyll concentration was obtained at a solvent to $A$. sessilis ratio of $5 \mathrm{~mL} / \mathrm{g}$. However, the extracted weight of chlorophyll was found to be increasing up to a ratio of $8 \mathrm{~mL} / \mathrm{g}$. This may be due to the dual effect of increase in the rate of extraction and dilution of the solution. Up to a solvent to A. sessilis ratio of $5 \mathrm{~mL} / \mathrm{g}$, the rate of extraction is significantly higher than the dilution. However the dilution effect dominates above $5 \mathrm{~mL} / \mathrm{g}$.

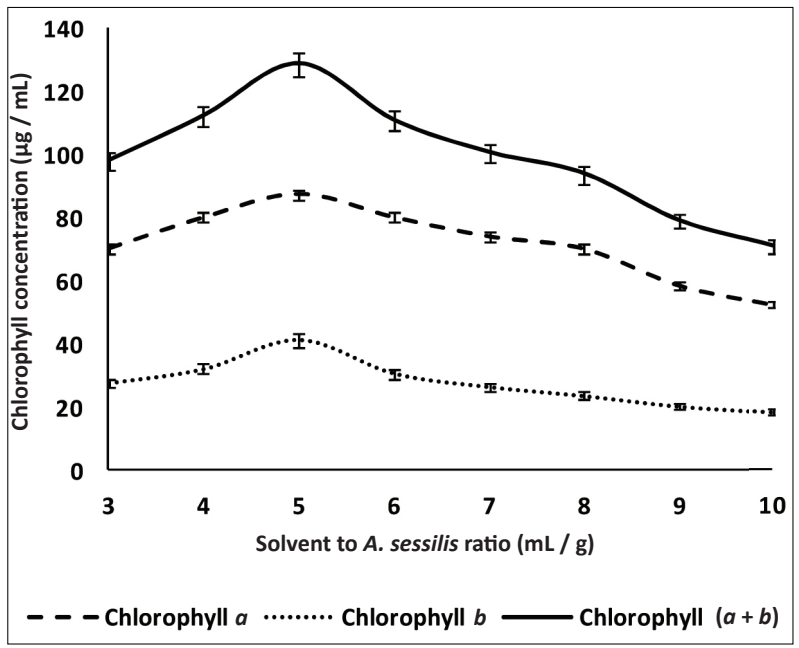

Figure 1: Variation of solvent volume on the concentration of chlorophyll $a, b$ and $a+b$
Therefore, considering the economy of operation, $5 \mathrm{~mL} / \mathrm{g}$ was selected as the optimum solvent to $A$. sessilis ratio, under $30{ }^{\circ} \mathrm{C}$ operating temperature and a time duration of 300 minutes. The corresponding concentrations obtained for chlorophyll $a, b$ and $a$ plus $b$ were $87.34,41.33$ and $128.67 \mu \mathrm{g} / \mathrm{mL}$, respectively with a chlorophyll $a$ to $b$ ratio of 2.12, and the weight of chlorophyll $a$ plus $b$ was $643.36 \mu \mathrm{g} / \mathrm{g}$.

\section{Optimum temperature of extraction}

The concentration of chlorophyll $a$ and $b$ in the extract with various extraction temperatures is shown in Figure 2. Chlorophyll extraction improves with the increase in temperature up to $50^{\circ} \mathrm{C}$. The degradation of chlorophyll may become prominent at high temperatures and prolong extraction. Therefore $50{ }^{\circ} \mathrm{C}$ was selected as the optimum temperature with extraction time not exceeding 2 hours.

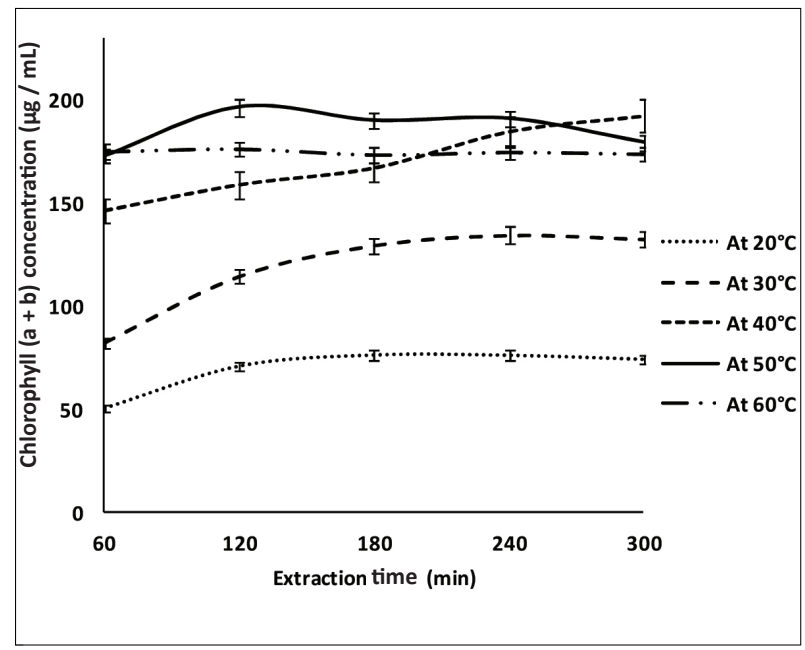

Figure 2: Effect of extraction temperature on concentration of chlorophyll $a+b$; solvent to $A$. sessilis ratio $5 \mathrm{~mL} / \mathrm{g}$ 


\section{Optimum time for extraction}

According to Figure 3, chlorophyll concentration increased gradually at the beginning and reached a constant value. After 45 minutes of extraction, the increase of chlorophyll $a$ plus $b$ became less significant and hence the optimum extraction time was selected as 45 minutes. The yield of chlorophyll $a$ and chlorophyll $b$ at 45 minutes of extraction was 659.5 and $261 \mu \mathrm{g}$ per gram of fresh A. sessilis, respectively. The corresponding values on dry basis were 3.879 and $1.535 \mu \mathrm{g}$ per milligram of $\operatorname{dry} A$. sessilis, respectively.

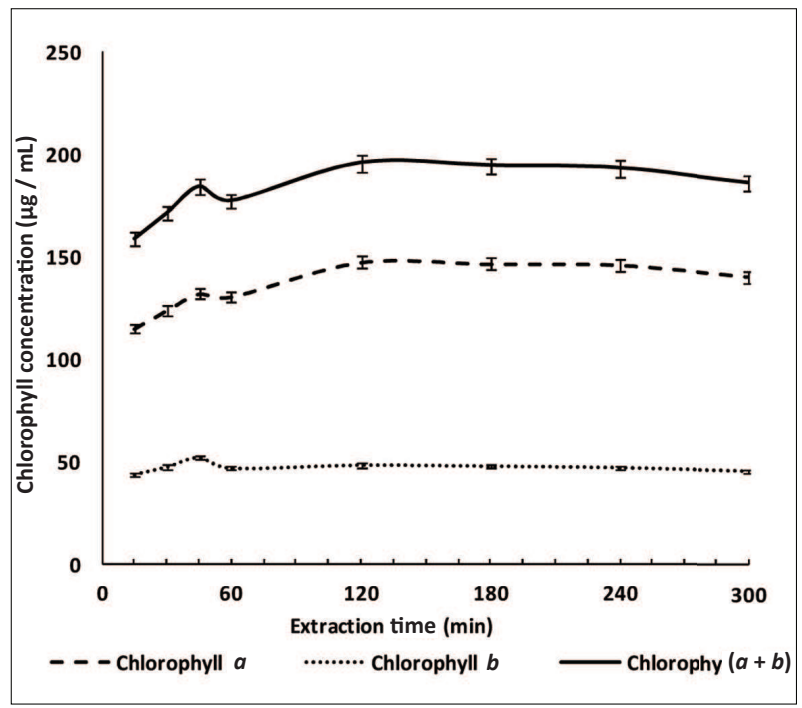

Figure 3: Effect of extraction time on chlorophyll concentration; temperature $50^{\circ} \mathrm{C}$, solvent to $A$. sessilis ratio $5 \mathrm{~mL} / \mathrm{g}$

\section{Comparison of the yield of chlorophyll extracted from A. sessilis with other plants}

Hojnik et al. (2007) have studied the isolation of chlorophyll from stinging nettle (Urtica dioica L.) using different preservation techniques and storage conditions. The yield was found to be $0.8 \mathrm{mg}$ of chlorophyll per gram of fresh nettle at a temperature of $20{ }^{\circ} \mathrm{C}$ and an extraction time of one hour with a solvent to nettle ratio of $10 \mathrm{~L} / \mathrm{kg}$ (Hojnik et al., 2007). Comparatively, the yield of chlorophyll $a$ plus $b$ was $0.9205 \mathrm{mg}$ of chlorophyll per gram of fresh $A$. sessilis.

Cubas et al. (2008) used N,N-dimethylformamide to extract chlorophyll in green beans (Phaseolus vulgaris L.) of cultivar Emerite. They have reported a maximum chlorophyll content of $13.3 \mathrm{mg}$ of chlorophyll per $100 \mathrm{~g}$ of fresh green beans (for five extractions, a 90 minute extraction time and 1 minute homogenisation time) (Cubas et al., 2008). The contents of chlorophyll a and chlorophyll $b$ were found to be 6.4 and $6.8 \mathrm{mg}$ per $100 \mathrm{~g}$ of fresh green beans, respectively. Furthermore Khalyfa et al. (1992) have reported that the extraction of chlorophyll from $100 \mathrm{~g}$ of fresh spinach leaves with methanol resulted in $38 \mathrm{mg}$ of chlorophyll $a$ and $13 \mathrm{mg}$ of chlorophyll $b$, while extraction with acetone resulted $61 \mathrm{mg}$ of chlorophyll $a$ and $29 \mathrm{mg}$ of chlorophyll $b$ (Khalyfa et al., 1992). Comparatively, the amount of chlorophyll $a, b$ and $a$ plus $b$ extracted from $A$. sessilis were $65.95,26.1$ and $92.05 \mathrm{mg}$ of chlorophyll per $100 \mathrm{~g}$ of fresh A. sessilis, respectively. Although the amount of chlorophyll $b$ extracted from $A$. sessilis was slightly lower than the amount extracted from spinach using acetone, both the amounts of chlorophyll $a$ and $a$ plus $b$ extracted from $A$. sessilis were higher than the reported values for green beans and spinach.

Barnes et al. (1992) have compared DMSO and acetone as solvents for the extraction of chlorophyll from several lichens and higher plants. The highest amount of chlorophyll extraction was observed from the lichen Ramalina farinacea collected from El Robledo, and the higher plant Trifolium repens out of the plants under investigation in their study using both the solvents (Barnes et al., 1992). The highest chlorophyll content found from the lichens and higher plants in this study and the comparative values for chlorophyll extracted from $A$. sessilis are given in Table 3 . The results suggest that $A$. sessilis contains a considerably higher amount of chlorophyll compared to other higher plants and vegetables.

\section{Mass transfer model for chlorophyll extraction}

Mass transfer of chlorophyll from $A$. sessilis to solvent was modelled by assuming that the rate of mass transfer from the solid surface to the liquid was the limiting factor. The following general mass transfer equation was used (Geankoplis, 2002).

$N_{a}=V \frac{d C_{a}}{d t}=A K_{L}\left(C_{a s}-C_{a}\right)$

Where;

$\mathrm{N}_{\mathrm{a}}$ - Rate of solute dissolving to the solution ( $\left.\mathrm{mol} / \mathrm{s}\right)$

A - Surface area of particles

$\mathrm{K}_{\mathrm{L}}$ - Mass transfer coefficient

$\mathrm{C}_{\mathrm{a}}$ - Concentration of solute at time $t$

$\mathrm{C}_{\text {as }}$ - Saturation solubility of solute in solution

$\mathrm{V}$ - Volume of the solution 
Table 3: Comparison of the chlorophyll content of A. sessilis with some of the plant materials used by Barnes et al. (1992)

\begin{tabular}{lllll}
\hline \multirow{2}{*}{$\begin{array}{l}\text { Plant material } \\
\text { Samalina farinace }\end{array}$} & DMSO & 2.2 & 0.53 & $\begin{array}{c}\text { Chlorophyll content } \\
(\mu \mathrm{g} / \mathrm{mg} \text { dry plant material })\end{array}$ \\
\cline { 3 - 5 } Ramalina farinacea & Acetone & 1.26 & 0.47 & 1.73 \\
Trifolium repens & DMSO & $2.486 \pm 0.11$ & $1.085 \pm 0.11$ & $3.571 \pm 0.17$ \\
Trifolium repens & Acetone & $2.55 \pm 0.15$ & $1.112 \pm 0.15$ & $3.662 \pm 0.16$ \\
A. sessilis & Acetone & 3.879 & 1.535 & 5.414
\end{tabular}

By integrating,

$\frac{C_{a s}-C_{a}}{C_{a s}-C_{a 0}}=e^{-\left(\frac{K_{L} A}{\mathrm{~V}}\right) t}$

Where, $C_{a 0}$ is the initial solute concentration.

Since $C_{a 0}=0$;

$C_{a}=C_{a s}-C_{a s} \times e^{-\left(\frac{K_{L} A}{\mathrm{~V}}\right) t}$

Where, $\frac{K_{L} A}{V}=K$ is a constant as all the samples were prepared from the same material, the solvent volume was kept constant and the extraction process was carried out at a constant temperature. Finally the mass transfer equation is simplified to,

$C_{a}=C_{a s} \times\left(1-e^{-K t}\right)$
The experimental results given in section 'Optimum temperature of extraction' were smoothed with Loess (quadratic) method using MatLab ${ }^{\mathrm{TM}}$. The smoothed concentrations of chlorophyll $a$ and $b$ were plotted against the extraction time and these data were used in curve fitting tool of MatLab ${ }^{\mathrm{TM}}$ to find the values of $C_{a s}$ and $K$ in mass transfer model corresponding to each temperature. Figure 4 shows both the predicted [using equation (7)] and smoothed experimental concentrations of chlorophyll $a$. Similar trends were observed for chlorophyll $b$ as well. The correlation coefficients $\mathrm{R}^{2}$ (coefficient of determination) and sum of squares due to error (SSE) values corresponding to the plots for each temperature are given in Table 4. The $\mathrm{R}^{2}$ and SSE values for temperatures 20 and $30{ }^{\circ} \mathrm{C}$ indicate better correlations of actual and theoretical data. For temperatures above $30{ }^{\circ} \mathrm{C}$, the predicted and actual data were significantly different. This may be due to the degradation of chlorophyll at elevated temperatures, which was not accommodated in the mass transfer model.

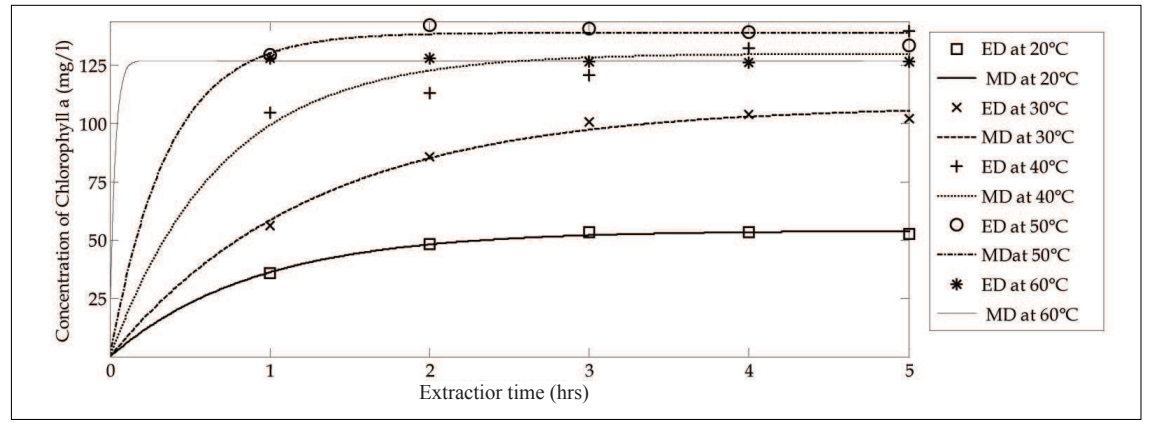

Figure 4: Comparison of experimental (ED) and model (MD) data of concentration of chlorophyll $a$ with extraction time at five different temperatures 
Table 4: Correlations of actual and predicted data

\begin{tabular}{cccc}
\hline $\begin{array}{c}\text { Temperature } \\
{ }^{\circ} \mathrm{C}\end{array}$ & Type & $\mathrm{R}^{2}$ value & $\mathrm{SSE}$ \\
\hline 20 & $\mathrm{Chl} a$ & 0.9856 & 3.322 \\
& $\mathrm{Chl} b$ & 0.9133 & 3.974 \\
30 & $\mathrm{Chl} a$ & 0.9836 & 2.648 \\
& $\mathrm{Chl} b$ & 0.6945 & 3.859 \\
40 & $\mathrm{Chl} a$ & 0.6415 & 261.6 \\
& $\mathrm{Chl} b$ & 0.5256 & 39.32 \\
50 & $\mathrm{Chl} a$ & 0.5635 & 49.81 \\
& $\mathrm{Chl} b$ & 0.7059 & 5.336 \\
60 & $\mathrm{Chl} a$ & Minus value & 2.796 \\
& $\mathrm{Chl} b$ & Minus value & 0.2055 \\
\hline
\end{tabular}

Table 5 shows the coefficients of mass transfer model at 20 and $30^{\circ} \mathrm{C}$. The increase of $K$ values with the increase in temperature agrees with the general characteristic of leaching behaviour for most of the solvent extraction processes.

Table 5: Coefficients of mass transfer model

\begin{tabular}{cccc}
\hline $\begin{array}{c}\text { Temperature } \\
{ }^{\circ} \mathrm{C}\end{array}$ & Type & $\begin{array}{c}\mathrm{C}_{\text {as }} \\
(\mu \mathrm{g} / \mathrm{mL})\end{array}$ & $\mathrm{K}\left(\times 10^{-4}\right)$ \\
\hline 20 & $\mathrm{Chl} a$ & 54.06 & 3.075 \\
& $\mathrm{Chl} b$ & 23.13 & 3.189 \\
30 & $\mathrm{Chl} a$ & 107.6 & 4.954 \\
& $\mathrm{Chl} b$ & 29.68 & 5.842 \\
\hline
\end{tabular}

\section{Determination of the effective storage condition for A. sessilis}

The weight of extracted chlorophyll $a$ plus $b$ obtained for different storage conditions are presented in Figure 5. The loss of chlorophyll is significantly low with refrigeration as compared to other storage conditions. The results indicate no significant difference between refrigeration at 15 and $5{ }^{\circ} \mathrm{C}$. Drying also reduces the loss of chlorophyll in long term storage, as compared to storing in ambient conditions. Moisture content of the dried samples at 40 and $70{ }^{\circ} \mathrm{C}$ were found to be 84 and $55 \%$, respectively. This may be the reason for better preservation of chlorophyll after drying at $70{ }^{\circ} \mathrm{C}$ as compared to drying at $40^{\circ} \mathrm{C}$.

\section{Effective method of pre processing of $A$. sessilis}

Figure 6 depicts that mechanical grinding (Pre 1) has given the highest yield, while grinding by mortar and pestle (Pre 4) has given the second highest yield. Pre processing may result in the degradation of chlorophyll and this effect is more significant with blanching (Pre 2 and 3) and

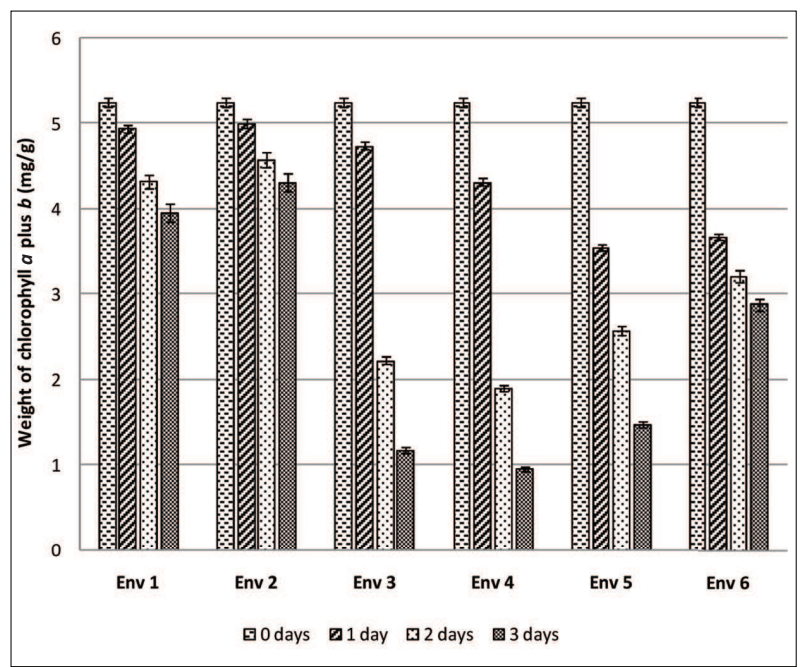

Figure 5: Effect of storage condition on the yield of chlorophyll $a+b$. The weight is presented in milligrams per $1 \mathrm{~g}$ of fresh $A$. sessilis

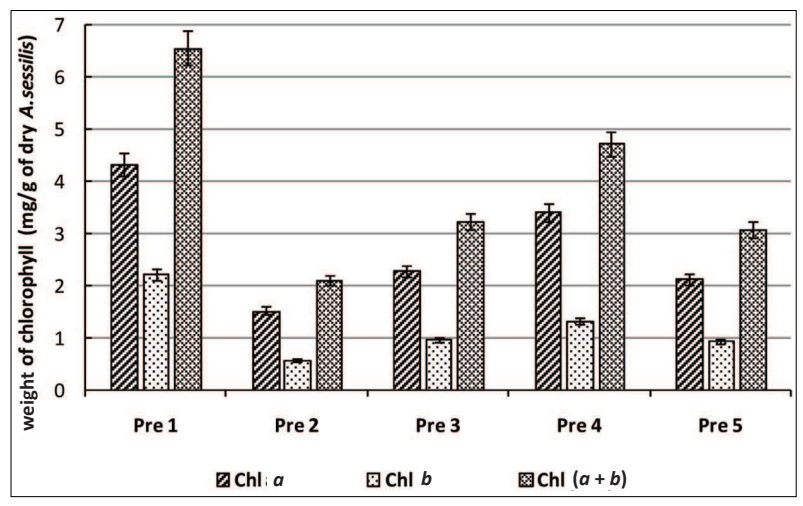

Figure 6: Weight of chlorophyll $a, b$ and $a+b$ for different preprocessing methods

drying (Pre 5). Further, the extraction of chlorophyll from A. sessilis may be promoted by disintegration of cell walls as in the case of grinding (Pre 1 and 4). Mechanical grinding (Pre 1) has given more yield than grinding by mortar and pestle (Pre 4) because of the better disintegration of cells by the motor driven grinding.

\section{Degradation kinetics of chlorophyll extracted from A. sessilis}

Chlorophyll degradation follows a first-order model (Hayakawa \& Timbers, 1977; Lichtenthaler, 1987; Canjura et al., 1991; Steet \& Tong, 1996; Ryan-Stoneham \& Tong, 2000; Koca et al., 2007; Erge et al., 2008; Rudra et al., 2008; Seema \& Keshav, 2010) and the effect of temperature on the rate constant can be adequately 
described by the Arrhenius equation (Lichtenthaler, 1987; Ryan-Stoneham \& Tong, 2000; Koca et al., 2007). A similar model was used to describe the degradation of chlorophyll extracted from $A$. sessilis at four different temperatures; $15,30,40$ and $50{ }^{\circ} \mathrm{C}$.

The first order kinetic model,

In $\frac{C}{C_{0}}=-k t$

where,

$C$ - The concentration at any time

$C_{0}$ - The concentration at time zero

$k$ - Rate constant at the reaction temperature

$t$ - Time
The Arrhenius equation,

$\operatorname{In} k=\operatorname{In} A_{0}-\left(\frac{E_{0}}{R}\right)=\frac{1}{T}$

Where,

$k$ - Rate constant

$A_{0}$ - Pre-exponential constant

$E_{0}$ - Activation energy

$R$ - Gas constant temperature in Kelvin

The experimental results and the model data for the normalised concentrations of chlorophyll $a$ and $b$ at $15^{\circ} \mathrm{C}$ is shown in Figure 7. Similar trends were observed for temperatures of 30,40 and $50^{\circ} \mathrm{C}$. Since the experimental data were well in agreement with the model data, rate

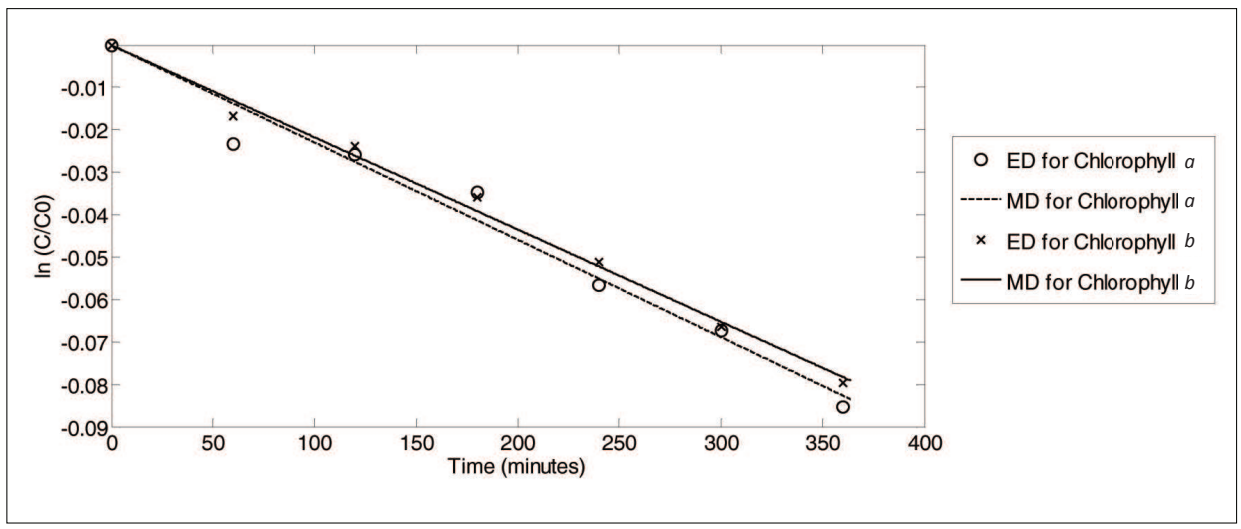

Figure 7: The relationship between the concentration of chlorophyll and time at $15^{\circ} \mathrm{C}(\mathrm{ED}$ - experimental data, MD - model data)

constant $k$ was calculated. The calculated rate constant values at four different temperatures have been tabulated in Table 6 with the corresponding $\mathrm{R}^{2}$ values.

Table 6: The rate constants at various temperatures

\begin{tabular}{cccc}
\hline & $\begin{array}{c}\text { Temperature } \\
\left({ }^{\circ} \mathrm{C}\right)\end{array}$ & $k$ & $\mathrm{R}^{2}$ value \\
\hline Chl $a$ & 15 & 0.0002296 & 0.9991 \\
& 30 & 0.0003053 & 0.9993 \\
& 40 & 0.0003506 & 0.9997 \\
$\mathrm{Chl} b$ & 50 & 0.0004079 & 0.9995 \\
& 15 & 0.0002175 & 0.9995 \\
& 30 & 0.0002777 & 0.9991 \\
& 40 & 0.0003278 & 1.0 \\
& 50 & 0.0003669 & 0.9995 \\
\hline
\end{tabular}

The plot of the logarithm of rate constant against $1 / \mathrm{T}$ shows a good correlation (Figure 8) with the Arrhenius equation with a minimum $\mathrm{R}^{2}$ value of 0.9985 . Therefore the values for $A_{0}$ and $E_{0}$ were calculated based on those data (Table 7). The $E_{0}$ values listed in Table 7 are for solutions of chlorophyll and that may be the reason for having very low values in comparable to the values found in literature on pastes and purees.

Table 7: Activation energy and $\mathrm{A}_{0}$ of chlorophyll

\begin{tabular}{lcc}
\hline & $\begin{array}{c}\text { Activation energy } \\
(\mathrm{kcal} / \mathrm{mol})\end{array}$ & $\mathrm{A}_{0}$ \\
\hline $\mathrm{Chl} a$ & 3.0143 & 0.0449 \\
$\mathrm{Chl} b$ & 2.78 & 0.0282 \\
\hline
\end{tabular}




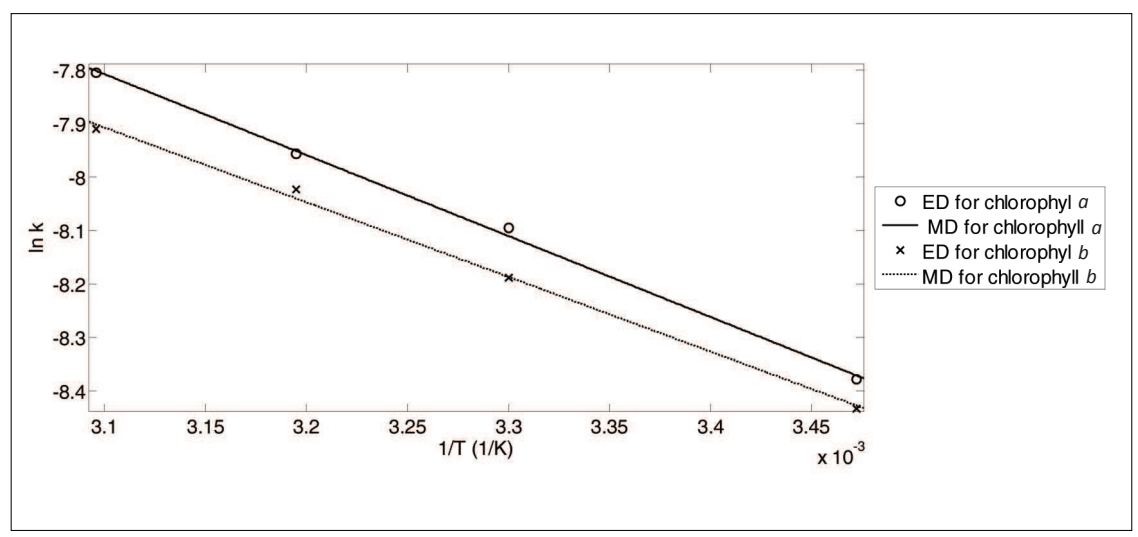

Figure 8: The relationship between the rate constant and the temperature (ED - experimental data, MD - model data)

\section{CONCLUSION}

The optimum operating conditions for the extraction of chlorophyll from $A$. sessilis using $80 \%(\mathrm{v} / \mathrm{v})$ acetone were found to be: solvent volume to $A$. sessilis weight ratio of $5: 1 \mathrm{~mL} / \mathrm{g}$, extraction temperature of $50{ }^{\circ} \mathrm{C}$ and extraction time of 45 minutes.

Comparison with other higher plant materials and vegetables suggests that $A$. sessilis is a good source for the extraction of chlorophyll. Under the above mentioned optimum conditions, the maximum extractable amount of chlorophyll $a$ and chlorophyll $b$ were 659.5 and $261 \mu \mathrm{g}$ per gram of fresh $A$. sessilis, respectively.

General mass transfer equation adequately describes the chlorophyll extraction using acetone as the solvent at temperatures up to $30^{\circ} \mathrm{C}$ but fails above this temperature due to degradation effects. Kinetic studies on the degradation of chlorophyll extracted from $A$. sessilis confirmed that chlorophyll degradation follows the first order kinetics and the temperature dependence of the rate constant can be modelled by the Arrhenius equation.

The study on the effect of storage conditions suggests that fresh $A$. sessilis retain the chlorophyll content without considerable loss under ambient conditions for one day. Refrigeration and/or freezing are better alternatives when compared with drying, for lengthy storage times. Mechanical disintegration of $A$. sessilis by grinding was found to be a better pre-processing technique as compared to blanching and drying for obtaining higher yields in the extraction of chlorophyll.

\section{Acknowledgement}

The authors express their gratitude to the financial support given by the Senate Research Council of the University of Moratuwa, Sri Lanka.

\section{REFERENCES}

1. Barnes J.D., Balaguer L., Manrique E., Elvira S. \& Davison W. (1992). A re-appraisal of the use of DMSO for the extraction and determination of chlorophylls $a$ and $b$ in lichens and higher plants. Environmental and Experimental Botany 32(2): $85-100$.

2. Canjura F.L., Schwartz S.J. \& Nunes R.V. (1991). Degradation kinetics of chlorophylls and chlorophyllides. Journal of Food Science 56(6): 1639 - 1643. DOI: http://dx.doi.org/10.1111/j.1365-2621.1991.tb08660.x

3. Chandrika G., Savenberg U. \& Jansz E.R. (2006). In vitro accessibility of $\beta$-carotene from cooked Sri Lankan green leafy vegetables and their estimated contribution to vitamin A requirement. Journal of the Science of Food and Agriculture 86: $54-61$.

DOI: http://dx.doi.org/10.1002/jsfa.2307

4. Chernomorsky S.A. \& Segelman A.B. (1988). Biological activities of chlorophyll derivatives. New Jersey Medicine 85(8): $669-673$.

5. Chernomorsky S., Segelman A. \& Poretz R.D. (1999). Effect of dietary chlorophyll derivatives on mutagenesis and tumour cell growth. Teratogenesis Carcinogenic and Mutagenesis 19: 313 - 322.

6. Cubas C., Lobo M.G. \& Gonzalez M. (2008). Optimization of the extraction of chlorophylls in green beans (Phaseolus vulgaris L.) by N,N-dimethylformamide using response surface methodology. Journal of Food Composition and Analysis 21: 125 - 133 .

DOI: http://dx.doi.org/10.1016/j.jfca.2007.07.007 
7. Dashwood R.H., Breinholt V. \& Bailey V. (1991). Chemo preventive properties of chlorophyllin: inhibition of aflatoxin B1 (AFB1)-DNA binding in vivo and anti-mutagenic activity against AFB1 and two heterocyclic amines in the Salmonella mutagenicity assay. Carcinogenesis 12(5): 939 - 942. DOI: http://dx.doi.org/10.1093/carcin/12.5.939

8. Erge H.S., Karadeniz F., Koca N. \& Soyer Y. (2008). Effect of heat treatment on chlorophyll degradation and colour loss in green peas. GIDA 33(5): $225-233$.

9. Fernandes T.M., Gomes B.B. \& Lanfer-Marquez U.M. (2007). Apparent absorption of chlorophyll from spinach in an assay with dogs. Innovative Food Science and Emerging Technologies 8: 426 - 432 .

DOI: http://dx.doi.org/10.1016/j.ifset.2007.03.019

10. Ferruzzi M.G. \& Blakeslee J. (2007). Digestion, absorption, and cancer preventive activity of dietary chlorophyll derivatives. Nutrition Research 27: 1 - 12.

DOI: http://dx.doi.org/10.1016/j.nutres.2006.12.003

11. Ferruzzi M.G., Bohm V., Courtney P.D. \& Schwartz S.J. (2002). Antioxidant and antimutagenic activity of dietary chlorophyll derivatives determined by radical scavenging and bacterial reverse mutagenesis assays. Journal of Food Science 67: $2589-2595$.

DOI: http://dx.doi.org/10.1111/j.1365-2621.2002.tb08782.x

12. Francis F.J. (2000). Wiley Encyclopedia of Food Science and Technology, $2^{\text {nd }}$ edition, pp. 391. John Wiley and Sons, New York, USA.

13. Gayathri B.M., Balasuriya K., Gunawardena G.S.P.D.S., Rajapakse R.P.V.J. \& Dharmaratne H.R.W. (2006) Toxicological studies of the water extract of green leafy vegetable sessile joy weed (Alternanthera sessilis). Current Science 91(11): 1517 - 1520.

14. Geankoplis C.J. (2002). Transport Processes and Unit Operations, $3^{\text {rd }}$ edition, pp. $725-726$. Prentice-Hall, New Delhi, India.

15. Hayakawa K. \& Timbers G.E. (1977). Influence of heat treatment on the quality of vegetables: changes in visual green colour. Journal of Food Science 42(3): 778 - 781. DOI: http://dx.doi.org/10.1111/j.1365-2621.1977.tb12601.x

16. Hojnik M., Skerget M. \& Knez Z. (2007). Isolation of chlorophylls from stinging nettle (Urtica dioica L.). Separation and Purification Technology 57: 37 - 46. DOI: http://dx.doi.org/10.1016/j.seppur.2007.02.018

17. Jalalpure S.S., Agrawal N., Patil M.B., Chimkode R. \& Tripathi A. (2008). Antimicrobial and wound healing activities of leaves of Alternanthera sessils (linn). International Journal of Green Pharmacy 2(3): 141 - 144.

18. Jayaweera D. (1981). Medicinal Plants (Indigenous and Exotic) used in Ceylon. The National Science Council of Sri Lanka, 47/5, Maitland Place, Colombo 07.

19. Jones I.D., White R.C. \& Gibbs E. (1963). Influence of blanching or brining treatments on the formation of chlorophyllides, pheophytins, and pheophorbides in green plant tissue. Journal of Food Science 28(1): 437 - 439. DOI: http://dx.doi.org/10.1111/j.1365-2621.1963.tb00223.x
20. Jordan F.L. (1998). Chlorophyll Based Fuel Additive for Reducing Pollutant Emissions. US Patent 5826369.

21. Kamat J.P., Boloor K.K. \& Devasagayam T.P.A. (2000). Chlorophyllin as an effective antioxidant against membrane damage in vitro and ex vivo. Biochemica Biophysica Acta 1487: 113 - 127 .

22. Khalyfa A., Kermasha S. \& Alli I. (1992). Extraction, purification and characterization of chlorophylls from spinach leaves. Journal of Agricultural and Food Chemistry 40: $215-220$.

DOI: http://dx.doi.org/10.1021/jf00014a010

23. Koca N., Karadeniz F. \& Burdurlu S.H. (2007). Effect of $\mathrm{pH}$ on chlorophyll degradation and colour loss in blanched green peas. Food Chemistry 100(2): $609-615$.

DOI: http://dx.doi.org/10.1016/j.foodchem.2005.09.079

24 Lichtenthaler H.K. (1987). Chlorophylls and carotenoids: pigments of photosynthetic membranes. Methods in Enzymology 148: 350 - 382 .

25. Macias-Sanchez M.D., Mantell C., Rodriguez M., De Martinez I.O.E., Lubian L.M. \& Montero O. (2007). Supercritical fluid extraction of carotenoids and chlorophyll a from Synechococcus sp. Journal of Supercritical Fluids 39: $323-329$.

DOI: http://dx.doi.org/10.1016/j.supflu.2006.03.008

26. Madrid R. \& Madrid J.M. (1990). Los colorantes en la alimentacion. Alimentacion, Equipos y Tecnologia 9(01): $185-191$.

27. Marquez U.M.L. \& Borrmann D. (2009). Chlorophylls. Handbook of Natural Colorants (eds. T. Bechtold \& R. Mussak), pp. 247. John Wiley and Sons, UK. DOI: http://dx.doi.org/10.1002/9780470744970.ch15

28. Matney T.S. (1980). Antimutagenic activities of common vegetables and their chlorophyll content. Mutation Research 77: $245-250$.

29. Porra R.J., Thompson W.A. \& Kriedemann P.E. (1989). Determination of accurate extinction coefficients and simultaneous equations for assaying chlorophylls $a$ and $b$ extracted with four different solvents; verification of the concentration of chlorophyll standards by atomic absorption spectroscopy. Biochemica Biophysica Acta 975: 384 - 394.

30. Rudra S.G., Sarkar B.C. \& Shivhare U.S. (2008). Thermal degradation kinetics of chlorophyll in pureed Coriander leaves. Food and Bioprocess Technology 1(1): 91 - 99. DOI: http://dx.doi.org/10.1007/s11947-007-0016-Z

31. Ryan-Stoneham T. \& Tong C.H. (2000). Degradation kinetics of chlorophyll in peas as a function of $\mathrm{pH}$. Journal of Food Science 65(8): 1296 - 1302.

DOI: http://dx.doi.org/10.1111/j.1365-2621.2000.tb10600.x

32. Sarkar D., Sharma A. \& Talukder G. (1994). Chlorophyll and chlorophyllin as modifiers of genotoxic effects. Mutation Research 318: 239 - 247.

33. Sartory D.P. \& Grobbelaar J.U. (1984). Extraction of chlorophyll $a$ from freshwater phytoplankton for spectrophotometric analysis. Hydrobiologia 114: 177 - 187. DOI: http://dx.doi.org/10.1007/BF00031869 
34. Seema \& Keshav A. (2010). Thermal degradation of coriander leaves: kinetic modelling. International Journal of Chemical Sciences 8(5): S568 - S577.

35. Shoaf W.T. \& Lium B.W. (1976). Improved extraction of chlorophyll $a$ and $b$ from algae using dimethyl sulfoxide. Limnology and Oceanography 21(6): 926 - 928.

DOI: http://dx.doi.org/10.4319/1o.1976.21.6.0926

36. Simon D. \& Helliwell S. (1998). Extraction and quantification of chlorophyll $a$ from freshwater green algae. Water Research 32(7): 2220 - 2223.

37. Steet J.A. \& Tong C.H. (1996). Degradation kinetics of green colour and chlorophylls in peas by colourimetry and HPLC. Journal of Food Science 61(5): 924 - 928.

DOI: http://dx.doi.org/10.1111/j.1365-2621.1996.tb10903.x

38. Sweeney J.P. \& Martin M. (1958). Determination of chlorophyll and pheophytin in broccoli heated by various procedures. Journal of Food Science 23(6): 635 - 647. DOI: http://dx.doi.org/10.1111/j.1365-2621.1958.tb17615.x
39. Thompson R.C., Tobin M.L., Hawkins S.J. \& Norton T.A. (1999). Problems in extraction and spectrophotometric determination of chlorophyll from epilithic microbial bio-films: towards a standard method. Journal of the Marine Biological Association of the United Kingdom 79(3): 551 - 558.

DOI: http://dx.doi.org/10.1017/S0025315498000678

40. Wang X.F., Xiang J., Wang P., Koyama Y., Yanagida S., Wada Y., Hamada K., Sasaki S. \& Tamiaki H. (2005). Dyesensitized solar cells using a chlorophyll $a$ derivative as the sensitizer and carotenoids having different conjugation lengths as redox spacers. Chemical Physics Letters 408: 409 - 414.

DOI: http://dx.doi.org/10.1016/j.cplett.2005.04.067

41. Wellburn A.R. (1994). The spectral determination of chlorophylls $a$ and $b$, as well as total carotenoids, using various solvents with spectrophotometers of different resolution. Journal of Plant Physiology 144: 307 - 313. 